\title{
GOOD GOVERNANCE DAN FORMASI KEBIJAKAN PUBLIK NEO-LIBERAL
}

Fakultas Ilmu Sosial dan Ilmu Politik Universitas Muhammadiyah Makassar

Jl. Sultan Alauddin No. 259 Makassar 90221

Telp. 0411 - 866972 ext. 107 Fax. 0411 - 865588

\begin{abstract}
ABSTRAK
$\mathbf{S}$ ejak kurun waktu beberapa tahun terakhir, diskursus good governance telah menjajah wacana publik dalam reformasi dan demokratisasi di Indonesia. Tulisan ini bermaksud mendekonstruksi diskursus good governance itu sendiri, apa sesungguhnya yang keliru atau bahkan mungkin apa yang latah diucapkan soal good governance. Tulisan ini berusaha untuk menunjukkan masuknya gagasan neo-liberal dalam imajinasi perubahan politik, ekonomi dan sosial yang digelindingkan di masa-masa akhir kepemimpinan Soeharto di awal 1990-an. Sebagaimana akan ditunjukkan dalam tulisan ini, gerakan yang berlabel governance ini justru semakin menjauh dari semangat governance yang sebenarnya. Secara singkat, gerakan good governance di Indonesia justru melenceng dari semangat governance yang mengedepankan akomodasi, kooperasi dan sinegi dalam kesetaraan antar pelaku. Hal ini membawa proses marginalisasi kebijakan ekonomi, sosial, kultural dan juga politik yang sejalan dengan nilai-nilai neo-liberal.
\end{abstract}

Kata kunci : good governance, kebijakan publik dan neo liberal

\section{A. PENDAHULUAN}

Beberapa tahun terakhir ini, terminologi good governance telah melanda seluruh lapisan masyarakat di seluruh pelosok nusantara. Slogan reformasi politik yang pernah sangat populer dan berenergi di tahun 1998-1999, ternyata tidak berusia terlalu lama, dan kemudian tidak banyak lagi digunakan. Namun, wacana good governance bisa tetap bertahan sekarang ini, dan seakan-akan menjadi simbol dari masuknya Indonesia dalam standar kehidupan global. Masyarakat desa yang tidak berbahasa Inggris pun bisa fasih untuk melafalkan good governance.

Dengan mudah kita menyaksikan atau mendengar dari dekat bahasa santun nan elok 'good governance', tetapi dengan sangat gampang pula di sekitar kita terlihat centang perenang terjadi korupsi sistematik, legalisasi 
suap antar lembaga kekuasaan, pelanggaran hak asasi manusia dan kebijakan imperial lainnya. Sepertinya, beda tipis antara apa yang disebut dengan 'good' (baik) dengan 'bad' (buruk) atau 'poor' (miskin) dalam tata kelola pemerintahan, karena keduanya berjalan seiring bak lintasan rel kereta yang didisain kuat menancap dengan 'bantalan' teori dan mistifikasi kekuasaan, yang keluar masuk stasiun mengangkut (baca: memperdagangkan) penumpang sebanyak-banyaknya. Persis seperti 'good governance' yang diinjeksikan dari negara satu ke negara lain yang menebarkan pengaruh tentang kebenaran absolut dalam pengelolaan administrasi dan manajemen publik (Wiratraman, 2008).

Dalam konteks Indonesia yang bergeliat dengan tuntutan reformasi, good governance tampil sebagai model transplantatif baru yang diyakini mampu mengobati birokrasi politik yang dinilai sarat korupsi, suap, dan penyalahgunaan kekuasan, termasuk berbagai pelanggaran hak-hak asasi manusia. Aparat birokrasi negara, dari Presiden di pucuk pimpinan negara hingga pemerintahan paling bawah, seragam mendendangkan good governance. Di level aktor-aktor non-negara pun tidak kalah, agenda organisasi nonpemerintah pun bicara banyak soal good governance, dan menjadikannya program kerja yang signifikan pada pasca 1998. Tidak begitu mengherankan program-program antikorupsi, pengawasan terhadap pemerintah maupun otonomi daerah, pengawasan peradilan, dan lain sebagainya. Begitupun para akademisi, lembaga ataupun negara donor, dan aktor-aktor lainnya berbincang hal yang sama soal pentingnya good governance.

Uniknya, lebih dari satu dekade reformasi berjalan sejak 1998, korupsi bukannya berkurang melainkan semakin menggurita. Birokrasi publik masih belum banyak berubah, dari mentalitas pelayanan yang buruk dan inefisien, praktek suap menyuap masih subur, dan berbagai pelanggaran hak-hak asasi manusia masih banyak terjadi. Intinya, negara yang korup masih belum bisa teratasi dengan good governance.

Tulisan berikut hendak mendekonstruksi diskursus good governance itu sendiri, apa sesungguhnya yang keliru atau bahkan mungkin apa yang latah diucapkan soal good governance. Tulisan ini berusaha untuk menunjukkan masuknya gagasan neo-liberal dalam imajinasi perubahan politik, ekonomi dan sosial yang digelindingkan di masa-masa akhir kepemimpinan Suharto di awal 1990-an. Sebagaimana akan ditunjukkan dalam tulisan ini, gerakan yang berlabel governance ini justru semakin menjauh dari semangat governance yang sebenarnya. Secara singkat, gerakan good governance di Indonesia justru melenceng dari semangat governance yang mengedepankan akomodasi, kooperasi dan sinergi dalam kesetaraan antar pelaku. Hal ini membawa proses marginalisasi ekonomi, sosial, kultural dan juga politik yang berkepanjangan. Oleh karena itu, di akhir tulisan ini berusaha dilontarkan gagasan untuk mengembangkan pola governance yang lebih demokratis dan berkeadilan.

\section{B. GOOD GOVERNANCE : LATAR BELAKANG \& SEJARAH PERKEMBANGAN}

Sejak akhir tahun 1980-an, istilah governance mulai digunakan untuk pengertian yang berbeda. Tatkala istilah governance dipopulerkan, perubahan penggunaan istilah dari government ke governance lebih dimaksudkan untuk menunjukkan perlunya gelombang baru reformasi pemerintahan. Istilah government reform, democracy dan sejenisnya, dianggap telah mengalami inflasi dan tidak mampu menarik perhatian untuk menggerakkan semangat reform. Oleh karena itu, diperlukan kemasan baru baru government reform kali ini adalah berbeda dengan reform yang ada sebelumnya. Menurut Rhodes (Pratikno, 2005) Penggunaan istilah governance digunakan untuk menegaskan perlunya arah dan semangat baru reformasi pemerintahan. Istilah governance telah digunakan untuk menegaskan signifikansi perlunya perubahan proses, metode dan capaian kepemerintahan.

Penggunaan istilah governance sebagai konsep yang berbeda dengan government, mulai dipopulerkan secara efektif oleh Bank Dunia sejak tahun 1989. Dalam laporannya yang sangat terkenal yang berjudul "Sub- 
Saharan Africa: From Crisis to Sustainable Growth". Dalam laporan ini, Bank Dunia (1989) mendefinisikan governance sebagai "exercise of political power to manage nation". Selanjutnya, laporan ini menekankan bahwa legitimasi politik dan konsensus merupakan prasyarat bagi pembangunan berkelanjutan. Aktor negara (pemerintah), bisnis dan civil society harus bersinergi membangun konsensus, dan peran negara tidak lagi bersifat regulatif, tetapi hanya sebatas fasilitatif. Oleh karena itu, Abrahamsen (Wiratraman, 2007) legitimasi politik dan konsensus yang menjadi pilar utama bagi Good Governance versi Bank Dunia ini hanya bisa dibangun dengan melibatkan aktor non-negara yang seluas-luasnya dan melimitasi keterlibatan negara (pemerintah).

Dengan merujuk pada kasus Afrika, argumen di seluruh laporan ini menekankan pemerintah adalah sumber kegagalan pembangunan. Oleh karena itu, untuk membangun kepemerintahan yang baik, maka pemerintah harus dikurangi (less government). Pemerintahan yang besar (big government) akan menjadi sumber dari ke-pemerintahan yang buruk (bad governance). Kepemerintahan yang buruk ini, dalam operasi-onalisasi Bank Dunia (Weiss 2000: 801) adalah pemerintahan yang tidak representatif serta sistem non-pasar yang tidak efisien, yang dalam prakteknya menjadi sumber kegagalan pemba-ngunan di Afrika (Pratikno, 2005).

Sejak saat itulah awal mula gelombang penyuntikan dalam upaya memberantas 'penyakit' di dunia ketiga dilakukan, dengan cara mewajibkan sejumlah persyaratanpersyaratan dari Bank Dunia (yang kemudian diikuti oleh lembaga dan negara donor lainnya). Krisis di Afrika telah membawa pesan yang jelas dalam memperkenalkan sebuah konsep baru untuk melawan apa yang diidentifikasi Bank Dunia sebagai sebuah 'crisis of governance' atau 'bad governance' (World Bank 1992). Tentu, dalam menyuntikkan ide-ide governance semacam itu, telah diusung pula diskursus sebagai "pemanis" agar bisa diterima dan terlegitimasi oleh kekuasaan diktatorial yang memang banyak berkuasa saat itu. Diskursus "pemanis" itu adalah promosi demokrasi yang memperkuat good governance baik sebagai tujuan maupun sebuah persyaratan kerjasama pembangunan. Wacana yang diinisiasi oleh Bank Dunia ini terus menggelinding, yang kemudian membuat good governance menjadi slogan yang populer, termasuk di Indonesia. Ide utama yang melihat pemerintah sebagai sumber masalah daripada sebagai solusi ini terus merambah, dan melahirkan pendefinisian governance yang lebih menekankan pada peran aktor-aktor di luar pemerintah (Wiratraman, 2007).

\section{TINJAUAN KONSEP GOOD GOVERNANCE}

Konsep governance menurut Stoker (Kurniawan, 2006) pengembangan dari gaya memerintah dimana batas-batas antara sektor publik dan sektor privat menjadi kabur. Pengaburan batas-batas ini sejalan dengan kebutuhan Negara-negara modern untuk lebih melibatkan mekanisme politik dan pengakuan akan pentingnya isu-isu yang menyangkut empati dan persanaan dari publik untuk terlibat, sehingga memberikan kesempatan untuk mobilisasi sosial dan politik. Pemerintah akan memilki peran yang penting dalam menciptakan lingkungan politik pemerintahan yang kondusif, sektor swasta menciptakan pekerjaan dan pendapatan, sedangkan masyarakat berperan positif dalam interaksi sosial, ekonomi dan politik (Rakhmat, 2009).

Dalam perspektif Bank Dunia (Wiratraman, 2008), governance diartikan sebagai hal kekuasaan yang ditujukan dalam manajemen sumberdaya sosial dan ekonomi negara untuk pembangunan. Pengalaman Afrika pasca krisis utang dan pasca perang dingin telah menjadi latar belakang dan iklim yang melukiskan desakan kekuatan pasar bebas dan demokrasi liberal. Good governance dalam konteks tersebut adalah imposisi politik hukum yang dikendalikan negara-negara industrial dan agen internasional (lembaga maupun Negara donor) dalam membentuk ketatapemerintahan yang berselerakan pasar (Stokke 1995; Gathii 1998). Inilah good governance yang lahir dari rahim agenda besar globalisasi yang dikonstruksi ideologi neo-liberal (Wiratraman, 2008).

Untuk menunjukkan perbedaan yang cukup tajam dengan definisi di atas, Tokyo Institute of Technology menegaskan bahwa 
"[t]he concept of governance refers to the set of values, norms, processes and institutions by which society manages its development and resolves conflict, formally and informally." (www.soc.titech.ac.jp). Dalam definisi ini, pengertian governance justru ditekankan pada perilaku dan kapasitas masyarakat untuk mengelola kepentingan bersama, termasuk kapasitas dalam memanfaatkan pemerintah dalam penyelesaian permasalahanpermasalahan publik (Pratikno, 2005).

Negara-negara besar yang tergabung dalam OECD mendefinisikan governance sebagai "the use of political authority and exercise of control in a society in relation to the management of its resources for social and economic development". Lebih spesifik, pemerintah Inggris, dalam hal ini ODA, menjelaskan karakteristik good government mencakup legitimasi, akuntabilitas, kompetensi, penghormatan terhadap hukum dan hak-hak asasi manusia. Bank Dunia mengemukakan karakteristik good governance sebagai: masyarakat sipil yang kuat dan partisipatoris; terbuka; pembuatan kebijakan yang dapat diprediksi; eksekutif yang bertanggungjawab; birokrasi yang profesional; dan aturan hukum yang jelas. Sementara itu, The Commission on Global Governance mengartikan governance sebagai "the sum of the many ways individuals and institutions, public and private, manage their common affairs". Dalam bahasa komisi ini, Weiss (Pratikno, 2005) governance merupakan proses yang berkelanjutan melalui mana perbedaan kepentingan diakomodasi dan diwujudkan dalam praktek.

Baik sebagai sound development management maupun sebagai democratic politics, reformasi ke arah good governance menekankan pada perlunya pengecilan peran pemerintah. Sebagaimana didefinisikan oleh Rhodes (1996), good governance dimaknai sebagai negara yang minimal (minimal state). Pengurangan peran pemerintah ini menuntut peran aktor di luar pemerintah yang lebih besar, antara lain Civil Society Organization, dan terutama pelaku pasar (market).

Melihat rumusan-rumusan governance di atas, kata kunci dalam konsep governance adalah konsensus melalui mana perbedaan kepentingan bisa diakomodasikan, dan sinergi bisa dibangun. Selain mengharapkan bekerjanya institusi negara secara baik, governance juga merujuk pada penguatan institusi-institusi pasar dan civil society untuk mengimbangi dominasi negara yang sebelumnya menjadi sumber kegagalan pembangunan. Pertanyaannya kemudian, apa yang perlu dipermasalahkan dengan governance? Apa kaitannya denga neoliberalisme dan impilkasi apa yang dilahirkan pada praktek administrasi dan mana-jemen publik?. Oleh karena itu, perdebatan tentang konsep governance dan good governance perlu didiskusikan pada level aplikasinya di dunia ketiga, khususnya diIndonesia, dan kemudian refleksi teoritik yang bisa dibangun dari situ.

\section{D.GOOD GOVERNANCE \& NEOLIBERALISME}

Kritik terhadap good governance bukanlah hal yang baru, karena banyak studi atau riset yang telah dilakukan untuk membongkar wacana ini dalam berbagai pendekatan, baik itu pendekatan politik, ekonomi, sejarah, hukum, sosiologi internasional, hubungan internasional dan pendekatan disiplin ilmu lainnya (Abrahamsen 2000; Bello 2002, 2005; Bendana 2004; George 1995; Parasuraman, et. al. 2004; Pieterse 2004; Quadir et al. 2001; Robinson 2004; Selznick 1969; Gathii 1998; Hosen 2003; Wiratraman 2007, 2008).

Bank Dunia merupakan pencetus gagasan yang memperkenalkannya sebagai 'program pengelolaan sektor publik' (public sector management program), dalam rangka penciptaan ketatapemerintahan yang baik dalam kerangka persyaratan bantuan pembangunan (Pratikno, 2005). Good governance dalam konteks ini merupakan "suara pembangunan". Sebagai "suara pembangunan", sesungguhnya ia lebih menampakkan pendisiplinan demokrasi atau model ketatapemerintahan tertentu. Krisis di Afrika telah membawa pesan demikian jelas dalam mencetuskan suatu konsep baru mengenai 'governance' untuk menentang apa yang disebut Bank Dunia sebagai suatu 'crisis of governance' atau 'bad governance' (World Bank 1992). Pengalaman Afrika pasca krisis utang dan perang dingin telah menggambarkan 
latar dari suatu iklim umum dalam menyokong pasar bebas dan demokrasi liberal, dan hal ini telah secara dahsyat menunjukkan betapa good governance sebagai pemaksaan politik hukum oleh negara industrialisasi maju dan agen internasional (termasuk lembaga maupun negara donor) dalam membentuk ketatapemerintahan pasar (Abrahamsen 2000; Stokke 1995; Gathii 1998).

Dalam konteks Asia, proyek-proyek good governance sesungguhnya telah lama di perkenalkan ke sejumlah negara, utamanya ke negara-negara yang memiliki ketergantungan atas bantuan hutang luar negeri. Proyek tersebut sama sekali tidak mempedulikan rezim yang berkuasa adalah rezim yang koruptif dan diktatorial. Di Indonesia, pada awal tahun 1990-an sudah mulai diperkenalkan model ketatapemerintahan yang ramah terhadap kepentingan pasar, melalui skenario program penyesuaian struktural. Meski-pun demikian, saat Soeharto masih berkuasa, proyek-proyek yang dikembangkan di Indonesia praktis gagal dan tidak bisa dipertanggung-jawabkan. Bahkan korupsi yang dilakukan atas bantuan hutang luar negeri tersebut diketahui Bank Dunia, namun Bank Dunia melakukan pembiaran atas hutang-hutang yang dikorupsi tersebut. Inilah yang disebut 'criminal debt' (hutang kriminal), yang ironisnya harus dibayar oleh rakyat dan dibebankan pada generasi bangsa pasca Soeharto (Winters 1999; 2002).

Jadi apa yang disebut sebagai 'bantuan' oleh Bank Dunia, sebenarnya merupakan proses sistematik penghancuran yang tidak hanya ditujukan pada rakyat saat rezim Soeharto berkuasa, melainkan pula ongkos 'pelanggengan kekuasaan diktator' yang memiliki konsekuensi panjang terhadap jutaan rakyat Indonesia di masa-masa berikutnya. Dalam situasi demikian, terlihatlah dengan jelas bahwa 'good governance' bersahabat dengan mekanisme-mekanisme siluman yang tidak berkepentingan atas demokratisasi dan hak asasi manusia.

Tekanan Bank Dunia dalam urusan pembaruan ketatapemerintahan kian menguat disuntikkan setelah terjadinya krisis finansial di Asia di paruh akhir 1990an. Praktek dan justifikasi Bank Dunia melalui diagnosa antara ketatapemerintahan yang 'buruk dan baik' menjadi wacana utama dalam mempengaruhi faktor-faktor kegagalan dalam konteks krisis tersebut, dan ini persis seperti apa yang telah dilakukan sebelumnya di Afrika pada 1980-an.

Seiring bersama dengan gerakan reformasi yang dilakukan oleh mahasiswa tahun 1998, seolah proponen neo-liberal diberi 'pintu masuk' untuk kembali menanamkan proyekproyeknya (juga melalui utang) kepada pemerintah. Ratusan juta dolar dikucurkan untuk pemerintah dalam membiayai pembaruan kebijakan publik dan institusi politik, hukum dan ekonomi, sehingga tak terelakkan bahwa good governance menjadi arus utama pembaruan birokrasi dan hukum sebagai penopang proyek ketatapemerintahan tersebut.

Desentralisasi yang terjadi di awal reformasi telah memuluskan dan menyuburkan wacana good governance, karena ia menjadi sesuatu yang seksi, segar, populer, dan diucapkan secara berulangkali baik oleh pejabat tinggi hingga level yang paling rendah di daerah. Tak terkecuali, agenda-agenda gerakan menjadi ikut pula termoderasi dan mempercayai good governance sebagai obat mujarab bagi tatanan birokrasi politik-ekonomi Indonesia.

Akademisi dan organisasi non-pemerintah pun latah mengucapkan wacana tersebut sebagai ikon baru yang menemani demokratisasi. Sejak reformasi bergulir, telah lahir banyak pusat studi maupun proyekproyek good governance yang dipesan melalui perguruan tinggi, dari mulai isu yang lekat dengan pembaruan hukum, pembaruan peradilan, desentralisasi, penganggaran, hingga soal legal drafting. Begitu juga organisasi non-pemerintah yang secara kuat pula mentransmisikan gagasan good governance melalui isu yang tidak jauh berbeda.

Mengapa transmisi wacana good governance tersebut demikian kuat diusung oleh Bank Dunia dan kemudian ditransplantasikan dengan rapi oleh agen-agen negara maupun non-negara? Kita bisa mulai membedahnya dari sisi konseptual, dan lalu dilanjutkan 
dengan memetakan bagaimana kerangka konseptual tersebut menjadi sangat dominan dipaksakan ke negara-negara selatan, termasuk di Indonesia.

Dalam laporannya tahun 1989, Bank Dunia (Wiratraman, 2007) telah mengekspresikan gagasan "Upaya untuk menciptakan suatu kemampuan lingkungan dan untuk membangun kapasitas-kapasitas akan dibuang bila konteks politik tidak mendukung. Pada akhirnya, pemerintahan yang baik memerlukan pembaharuan politik. Ini berarti suatu tindakan bersama melawan korupsi dari tingkat paling tinggi hingga paling rendah. Hal ini dapat dilakukan dengan menata suatu contoh baik, dengan memperkuat pertanggung-jawaban, dengan mendukung debat publik, dengan memelihara suatu pers bebas. Ini juga berarti membantu perkembangan akar rumput dan orga-nisasi non-pemerintah seperti serikat petani, perkumpulan-perkumpulan, dan kelompok-kelompok perempuan".

Dengan langgam bahasa yang hampir sama, Bank Dunia telah menyatakan pula, “Good governance dilambangkan dengan dapat diperkirakan (predictable), terbuka (open) dan pembuatan kebijakan yang tercerahkan (enlightened policy-making), suatu birokrasi diilhami dengan ber-tindak etos professional dalam pemajuan fasilitas publik, rule of law, proses-proses transparan, dan masyarakat sipil yang kuat berpartisipasi dalam kepentingan publik. Ketatapemerintahan yang miskin (poor governance) di sisi lain dikarakteristikan dengan pembuatan kebijakan yang sewenangwenang, birokrasi yang tidak dapat dipertanggungjawabkan, sistem perundangan yang tidak adil dan tidak bisa ditegakkan, penyalahgunaan kekuasaan eksekutif, suatu masyarakat sipil yang tidak bisa menikmatik kehidupan publiknya dan korupsi yang meluas." (World Bank 1994: vii).

Dalam mengkampayekan good governance, Bank Dunia telah memprogramkan suatu program pembelajaran dan telah memperkenalkan konsep ketatapemerintahan. Good governance merupakan suatu manual yang didefinisikan sebagai implementasi efektif kebijakan dan provisi pelayanan yang responsive terhadap kebutuhan-kebutuhan warganya. Good governance melekat pada kualitas, seperti akuntabilitas, responsif, transparan, dan efisiensi. Ia mengasumsikan kemampuan pemerintah untuk mengelola sosial, perdamaian, jaminan hukum dan tatanan, mempromosikan dan menciptakan kondisi-kondisi yang perlu untuk pertumbuhan ekonomi dan mamastikan suatu level minimum jaminan sosial (World Bank 2002). Definisi yang demikian sesuangguhnya telah tetap dan secara kuat dipertahankan untuk menyokong aturan main bahwa membuat pasar bekerja secara efisien dan lebih problematiknya, Bank Dunia mengoreksi kegagalan pasar (Bank Dunia 1992).

Sejumlah dokumen tersebut memperlihatkan bahwa pendekatan yang digunakan oleh Bank Dunia, khususnya dalam menegaskan isu-isu penting akuntabilitas, sesungguhnya ditujukan dalam rangka mengupayakan pembaharuan untuk stabilitas politik dan pembangunan ekonomi yang diperlukan dalam proses liberalisasi pasar. Konsep politik ekonomi yang demikian sesungguhnya berfokus pada model demokrasi liberal dan liberalisasi ekonomi, dan good governance-nya pun merupakan model neo-liberal, yakni 'good governance free market assistance' (Wiratraman 2008).

Watak neo-liberalisme good governance dapat dilihat dari sasaran-sasarannya yang senantiasa berpusat pada efisiensi pengelolaan sumberdaya dan menopang pasar bebas. Elemen-elemen kuncinya adalah akuntabilitas, rule oflaw, transparan, dan partisipasi. Sungguh, elemen-elemen ini juga menjadi kebutuhan masyarakat Indonesia di tengah eforia reformasi, namun elemen kunci tersebut sebenarnya menyimpan rencana besar untuk melucuti peran-peran negara di sektor publik dan menggantikannya dengan peran dominan swasta atau privat. Urusan perlindungan hakhak asasi manusia bukanlah urusan yang penting dalam skema good governance ini, meski pun mandat tanggung jawab hak asasi manusia bertumpu pada peran utama negara good governance yang demikian hanya akan menempatkan posisi pasar secara dominan, dan urusan-urusan publik yang dimaksudkan pun telah diseleksi (baca: dipangkas) berbasis pada iklim liberalisasi pasar. 


\section{E. HEGEMONI GOOD GOVERNANCE DI INDONESIA}

Mengapa good governance tiba-tiba muncul, lazim dan bertahan lama sebagai model ketatapemerintahan di Indonesia yang banyak dituturkan, diikuti dan diajarkan? Mengapa secara cepat 'pemerintahan yang baik' menjadi akrab dengan dunia birokrasi, dunia usaha, dunia kampus dan pusat-pusat studi (yang juga tumbuh subur bak jamur di musim hujan), dunia aktivisme orga-nisasi non-pemerintah (utamanya yang bergerak di isu kebijakan publik dan antikorupsi), dan yang paling aneh tapi nyata, hampir semua lembaga-lembaga dana internasional dan negara-negara donor serempak menggerojok (baik utang maupun hibah) milyaran US dollars untuk proyek good governance? Padahal Bank Dunia sendiri sesung-guhnya gagal melakukan good governance secara internal, karena dipenuhi dengan korupsi sistemik dan motif ekploitasi terhadap negaranegara yang berutang kepadanya.

Pendapat mengatakan bahwa kemunculan proyek-proyek good governance yang cukup sukses adalah terkait dengan kesuksesan model negara pembangunan (developmental state model) diantara negara-negara industrialisasi baru di Asia Timur dan Asia Tenggara (Tshuma 1999; White 1987; Wade 1990). Pendapat lainnya mengatakan bahwa ideologi neo-liberal telah melesat setelah runtuhnya komunisme dan membangun suatu suasana kondusif bagi kelahiran governance sebagai sebuah isu pembangunan, dan karena neo-liberalisme sebagai ideologi dominan mencoba untuk mengkonstruksi 'politically lock-in neo-liberal reforms' (Gill, 1997).

Kedua pendapat di atas relevan dengan kemunculan good governance di Indonesia, karena selain kebijakan pemerintah yang berorientasikan pembangunan semasa Orde Baru, dukungan Bank Dunia dan IMF dalam mengguyurkan utang yang disertai persyaratan-persyaratan khusus melengkapi posisi Indonesia yang mengarah pada disain liberalisasi pasar. Tetapi bila dilihat secara lebih dalam, dengan menggunakan analisis hegemoni, nampak bahwa good governance bekerja dengan menggunakan rasionalitas dan teknologi kekuasaan untuk menghasilkan mesin yang halus dan efektif bagi upaya liberalisasi pasar. Hukum sebagai instrumentasi politik dipakai sebagai legalisasi beroperasinya mesin kekuasaan tersebut, sehingga jauh dari cerminan rasa keadilan dan perlindungan terhadap kaum proletar (Wiratraman, 2008).

Bank Dunia sendiri dalam mempromosikan good governance di Indonesia melalui tiga pintu: (i) CGI (Consultative Group on Indonesia); (ii) Kemitraan untuk Pembaruan Tata Pemerintahan (Partnership for Governance Reform); dan (iii) Justice for the Poor. Dalam forum tahunan CGI, Bank Dunia memimpin dan memiliki kekuasaan untuk mengarahkan (mendikte) kebijakan ekonomi (termasuk desakan pembentukan peraturan perundangundangan). Ini bisa terjadi karena pemerintah masih menerima kucuran utang sehingga prasyarat utang tersebut harus dipenuhi sebagai kompensasinya. Sedangkan Bank Dunia pula bekerja secara dekat dengan UNDP dan ADB sebagai sponsor dana utama untuk Partnership for Governance Reform (World Bank 2003). Melalui forum kelompok multistakeholder di Kemitraan ini, Bank Dunia telah terlibat aktif dalam membuat kerangka kerja hukum untuk pembangunan (legal framework for development), seperti pembaruan peradilan, pembaruan hukum, dan pembentukan lembaga pemerintahan baru (World Bank 2003). Pengaruh besar kemitraan ini adalah justru peran hegemoninya sebagai lembaga dana untuk proyek-proyek governance yang dijalankan oleh tidak saja lembaga negara, namun juga organisasi non-pemerintah. Sedangkan Justice for the Poor adalah sebuah institusi yang baru-baru saja dikreasi Bank Dunia dalam mempromosikan pengurangan kemiskinan di Indonesia, khususnya sebuah strategi pemberdayaan untuk kaum miskin melalui bantuan hukum.

Bagi Bank Dunia, program-program pemberdayaan dan penyadaran hukum merupakan hal penting dalam mewujudkan kaum miskin atas akses keadilan. Dalam urusan pemantauan korupsi, Bank Dunia sendiri memilih menfokuskan lebih banyak 
pada proyek-proyek yang didanainya sendiri (World Bank, 1997), semacam kini PNPM (Program Nasional Pemberdayaan Masyarakat). Kedua institusi terakhir menjadi kendaraan Bank Dunia untuk ikut pula mempromosikan hak-hak asasi manusia di Indonesia. Proyek pembaruan ketatapemerintahan melalui good governance cenderung untuk melayani promosi konsensus pembaruan sosial dan ekonomi, khususnya dengan mengaplikasikan pemberdayaan teknokratik dan bahasa liberal partisipasi. Di titik ini, diskursus dan arah kecenderungan hak-hak asasi manusia lebih menyesuaikan dengan liberalisasi pasar. Inilah yang disebut 'market friendly human rights paradigm' (paradigma hak-hak asasi manusia yang ramah pasar) (Wiratraman, 2008).

Strategi Bank Dunia untuk mempertahankan hegemoninya adalah dengan mereproduksi pengetahuan soal rasionalitas good governance sehingga memudahkan bekerjanya teknologi kekuasaannya melalui berbagai pintu masuk di level negara, non negara maupun kemitraan keduanya. Realitasnya, wacana-wacana ketatapemerintahan, pembaruan hukum dan kebijakan publik lainnya dikonstruksi dengan mengikutsertakan demokrasi, hak asasi manusia, anti kemiskinan, antikorupsi, yang kesemuanya terasa cocok dengan suasana (perangkap) reformasi yang sudah dikendalikan pendukung neo-liberal. Semakin lengkap adalah teknologi kekuasaan modalnya yang mampu memistifikasi ketidakseimbangan kekuasaan dan menyedot perhatian arah reformasi yang 'good', melalui program pendanaan ke sejumlah institusi negara, organisasi non-pemerintah, serta kampuskampus melalui pusat-pusat studi governance. Godaan untuk mengakses dana proyek governance tersebut terlampau besar, sehingga tidak sedikit yang mengubah pula rencana dan pola kerja organisasi penerima dana tersebut. Donor-driven hegemony!

\section{F. GOOD GOVERNANCE DAN PEMBARUAN KEBIJAKAN PUBLIK}

Selain dirumuskan dengan merujuk pada mekanisme pasar yang dianggap paling efisien dalam pengelolaan sumberdaya, good governance juga dirumuskan sebagai pola pemerintahan yang demokratis. Dalam bahasa Bank Dunia (1989 \& 1992), selain disebabkan oleh porsi pemerintah yang terlalu besar, kegagalan pembangunan juga diakibatkan oleh pemerintahan yang tidak demokratis, dan otoritas negara yang dipersonifikasi dalam diri satu atau sedikit orang pemimpin. Oleh karena itu, good governance juga mendorong demokratisasi dengan cara memaksa negara untuk berbagi kekuasaan dengan aktor-aktor di luar negara.

Diakui memang, bahwa telah terjadi banyak perubahan yang cukup banyak termasuk lompatan-lompatan pembentukan dan kerja kelembagaan negara yang kian melengkapi percaturan politik kenegaraan Indonesia. Proyek-proyek pembaruan tata pemerintahan dilakukan secara serentak, mulai dari upaya pembaruan hukum, pembaruan standar kinerja, dan pembaruan lembaga-lembaga negara lainnya.

Bagi Bank Dunia, pembaruan administrasi dan manajemen sektor publik dilihat sebagai faktor-faktor penting untuk memperkuat pembangunan dan pertumbuhan ekonomi. Untuk mendukung pertumbuhan ekonomi dan sistem pasar bebas, salah satu elemen prinsip good governance adalah 'legal framework for development' (kerangka perundang-undangan untuk pembangunan) (World Bank 1992). Dalam kerangka perundangan yang demikian, rule of law adalah konsep utama yang secara instrumental dan substansial penting, karena ia mengkonsentrasikan pada keadilan (justice), kejujuran (fairness) dan kebebasan (liberty). Bank Dunia menegaskan suatu sistem hukum yang 'fair', yang kondusif untuk menyeimbangkan pembangunan (World Bank 1992: 29-30). Ini sebabnya, tidak terlampau mengejutkan, perspektif Bank Dunia dalam good governance terkait utamanya dengan kebutuhan-kebutuhan perundangan bagi aktor-aktor komersial dalam pasar.

Dalam arena politik domestik, implikasi pelaksanaan good governance juga sangat jelas. Di satu sisi, good governance telah terbukti mendobrak keangkuhan negara yang selama ini menghegemoni masyarakat. Personifikasi kekuasaan negara pada 
sekelompok kecil elit, kebuntuan akses masyarakat terhadap kebijakan publik, dan lemahnya penegakan hak asasi manusia telah bisa didobrak oleh gelombang good governance. Namun, kekuasaan hegemonik yang menindas rakyat tidak secara otomatis lumpuh. Kekuasaan hegemonik hanya beralih dari kontrol negara ke kontrol swasta (kapital), yang oleh Korten (Pratikno, 2005) yang dalam kasus Indonesia pasca krisis 1998-2002 adalah perusahaan multinasional.

Implikasi dari hegemoni swasta bagi masyarakat umum ini tidak kalah buruk dibandingkan dengan implikasi hegemoni negara. Walaupun terdapat banyak program pengentasan kemiskinan, namun jumlah penduduk di bawah garis kemiskinan tidak mengalami pengurangan yang berarti, atau bahkan memburuk di beberapa negara. Penyakit busung lapar tetap dengan mudah ditemukan tatkala praktek kepemerintahan telah mulai menerapkan ciri-ciri good governance, seperti partisipasi dan transparansi. Lalu, apa makna good governance bagi masyarakat marjinal yang tidak mampu menjadi customer yang kuat di era liberalisasi ekonomi ini? Di sinilah neo-liberalisme bekerja rapi. Filho dan Johnston (Wiratraman, 2008) mengingatkan bahwa di bawah neoliberalisme, pertumbuhan ekonomi telah menurun, pengangguran meluas, ketidaksejajaran dalam maupun di antara negaranegara kian memburuk menyeluruh di mana saja, dan kaum marginal akan secara massif tertindas dari ketidakstabilan ekonomi.

Dalam konteks Indonesia, tekanan desain kebijakan publik neo-liberal sangat jelas terlihat ketika upaya pembaruan hukum tidak meletakkan arah perubahannya pada sistem yang lebih berkeadilan bagi rakyat banyak, melainkan lebih menuruti kepentingan atau selera pasar dalam penciptaan iklim usaha. Salam satunya yang paling menyakitkan bagi buruh adalah pembentukan institusi peradilan khusus bagi buruh melalui UU tentang Penyelesaian Perselisihan Hubungan Industrial (PPHI), Undang-Undang Badan Hukum Pendidikan, UU Migas, UU Penanaman Modal dll. Proyek pembaruan hukum yang disponsori Bank Dunia, secara implementatif tentu saja berdampak pada praktek administrasi dan manajemen publik, yang oleh Prasodjo (Kurniawan 2006) berupa debirokratisasi organisasi internal, modernisasi birokrasi, dan peningkatan kapasitas aparat birokrasi.

Sektor publik di perhadapakan pada seperangkat harapan baru dari masyarakat, bahwa sektor publik atau pemerintah perlu dikelola secara efisien (Rakhmat, 2009). Kondisi ini tentu menjadi prasyarat untuk meningkatkan kualitas pelayanan publik disatu sisi dan pada sisi yang lain menjadi ruang partisipasi masyarakat dalam kegiatan publik (Kurniawan, 2006). Seluruh fenomena ini merupakan implikasi proyek-proyek good governance Bank Dunia, yang senantiasa ditujukan pada pendisiplinan ketatapemerintahan yang berorientasikan pada kesetiaan pada liberalisasi pasar. Mekanisme pasar yang dikampanyekan dalam good governance ternyata dimanipulasi menjadi prosedur semu tanpa ada kapasitas negara untuk mendisiplinkannya.

\section{G PENUTUP}

Tidak semua persoalan yang digambarkan di atas diakibatkan oleh kampanye good governance yang ditekankan pada 'sound development management' yang menjadi "perangkap" agenda neo-liberal. Konsep dan ide good governance disadari ataupun tidak telah menjadi "narasi besar" reformasi birokrasi publik di Indonesia. Namun, permasalahan tersebut berkembang sebagai akibat dari wacana dan praktek pembaruan kebijakan publik di Indonesia yang tidak mengalami kontekstualisasi secara memadai, gagasan reformasi yang terfragmentasi, dan gagasan reformasi yang tidak tumbuh dari pelakupelaku di lapis bawah. Tulisan ini juga tidak dimaksudkan untuk mengatakan bahwa tekanan eksternal tidak penting dalam agenda reformasi pemerintahan di Indonesia. Namun, agenda reformasi yang yang terjebak pada perubahan teknikalitas pemerintahan dan pada birokrasi proyek akan mengakibatkan agenda kebijakan publik tersebut kehilangan roh dan tujuan akhir yang lebih bermakna bagi masyarakat. 
Argumen para penganjur neo-liberal yang menyatakan bahwa penjaminan hak-hak politik individu dan proses demokratisasi akan mendukung pengembangan kepemerintahan yang baik tidaklah salah. Namun, paket ini harus dipadukan dengan hak-hak sosial dan ekonomi individu sebagai paket integratif yang tidak terpisahkan. Penjaminan hak sosial dan ekonomi ini tidak bisa diberlakukan sebagai produk dari good governance semata, tetapi harus menjadi bagian dari proses pengembangan kepemerintahan yang baik. Oleh karena itu, sebagaimana digagas oleh Mahbub ul Haq (Pratikno, 2005), pengembangan kepemerintahan yang baik perlu dipadukan dengan konsep humane governance yang mencakup "good political, economic and civic governance".

Gagasan ini perlu ditelusuri lebih jauh, dan perlu dikontekstualisasikan dengan potensi dan problema Indonesia kontemporer. Pada saat yang sama, gagasan Denhart dan Denhardt (2003) tentang The New Public Service perlu untuk diperhitungkan sebagai inisiatif awal. Pada intinya, mempertahankan posisi individu sebagai citizen dan meminta pemerintah untuk lebih bertanggung jawab menjamin hak-hak sosial dan ekonomi adalah sesuatu yang vital, selain hak-hak politik.

\section{DAFTAR PUSTAKA}

Birkland, Thomas A. 2005. An Introduction to the Policiy Process: Theories, Concepts, and Models of Public Policy making. (Ed. 2th) New York: M.E. Sharpe, Inc.

Dye, Thomas R. 2005. Understanding Public Policy (ed. $7^{\text {th }}$ ).USA: Prentice Hall.
Grindle, Merilee S. 1997. Getting Good Government: Capacity Building in the Public Sectors of Developing Countries. Boston: Harvard University Press.

Kurniawan, Teguh 2006. Pergeseran Paradigma Adminsitrasi Publik : Dari Perilaku Model Klasik dan NPM ke Good Governance, Program Doktor Ilmu Adminsitrasi Negara Sekolah Pascasarjana UGM : Komponen Tugas Mata Kuliah Good Governance.

Putra, Fadillah (2009) Senjakala Good Governance, Malang : Pustaka Avveroes

Pratikno (2005) Good Governance dan Governability, Jurnal Sosial Politik, Vol. 8 No. 3, Maret 2005 (231-248).

Rakhmat (2009) Teori Administrasi dan Manajemen Publik, Jakarta : Pustaka Arief.

Stoker, G., 1991. The Politics of Local Government, (2nd Edition), London: Mac Millan.

Wiratraman, RH Perdana (2007) NeoLiberalisme, Good Governance, dan Hak Azasi Manusia, Jurnal JENTERA $X V$ : Januari-Maret 2007 (1-14).

Wiratraman, RH Perdana (2007) Good Governance dan Mitos Ketatanegaraan Neo-Liberal, Jurnal BERSATU : Mei 2008 (1-11). 